\title{
The 100th Anniversary of GMU - From Tczew Maritime School to Gdynia Maritime University
}

\author{
A. Weintrit \& A. Czarnecka \\ Gdynia Maritime University, Gdynia, Poland
}

\begin{abstract}
This year the 8th of December was very important date for Gdynia Maritime University. It was the 100th anniversary of the ceremonial opening of the Maritime School in Tczew and the flag-raising of the Polish Merchant Navy on the school building. Over the course of the century, the name and location of the University has changed, but one thing that has remained unchanged to this day is the serving of the Polish sea. 2020 is also a special year for all the world affected by the coronavirus pandemic. Unfortunately, the restrictions in force introduced changes to the program on the 100th Anniversary of GMU. In the changed formula, the celebrations on December 8, was held according to the modified plan adopted by the University.
\end{abstract}

\section{INTRODUCTION}

The rich history of Gdynia Maritime University started with the document signed on 17th June 1920 by Gen. Józef Leśniewski, by which the Maritime School in Tczew was set up. The organizers of the first Polish Maritime School strongly believed that the education of future officers of the merchant fleet must be realized, first of all, during sea-deep voyages. Thus, it was necessary to purchase the appropriate ship. The Polish flag was hoisted on the training ship, named "Lwów", on 4th September 1921 and the School inaugurated its activities in two faculties: Navigation Faculty and Marine Engineering Faculty.

In 1930 the decision was made to move the Maritime School from Tczew to Gdynia. In the academic year 1930/1931 the "Lwów" with its distinguished service was replaced by another training sailing ship "Dar Pomorza". In 1938 the Faculty of Transport and Maritime Administration was established. Gradually, new faculties were created and new specializations were introduced; so at the end of 60s of last century the School had in its structure three faculties: Navigation Faculty, Marine Engineering Faculty and Administration-Economic Faculty.

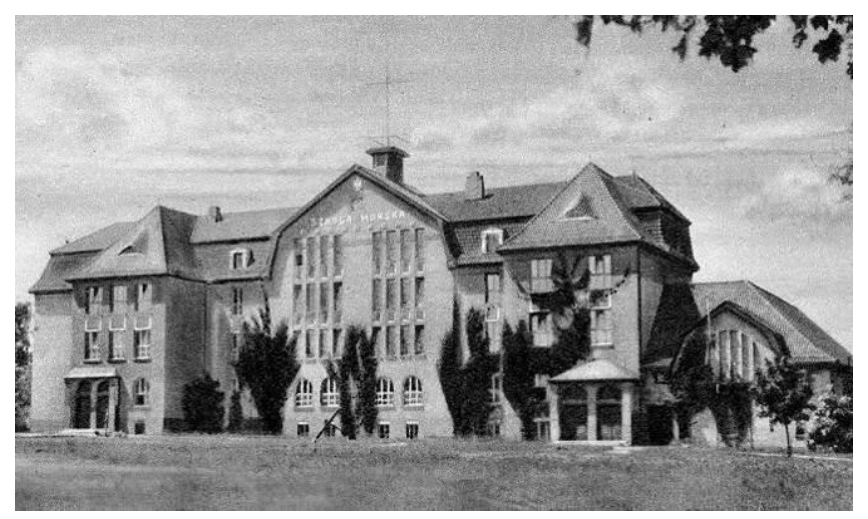

Figure 1. Main building of Maritime School in Tczew, 1920

In 1958 the State Maritime School obtained the status of post-secondary technical higher school and 
ten years later it merged with the State School of the Deep Sea Fishing. At last, in 1968 the School became the Maritime Academy. At that time the Academy could educate students in four faculties, in 16 specializations. Two new training ships started their operation: in 1982 the beautiful sailing ship "Dar Młodzieży" and in 2000 the modern research and transport training ship "Horyzont II".

Nowadays, Gdynia Maritime University has four, rapidly expanding faculties: Electrical Engineering, Management and Quality Science, Marine Engineering and Navigation. All the Faculties enable the university to develop and perform its scientific and didactic activities in the 9 fields of studies, in 43 specializations. They are also all authorized to grant a doctor degree.

\section{CELEBRATIONS OF THE 100TH ANNIVERSARY OF GMU}

The Year 2020 was very important date for Gdynia Maritime University. This year the 8th of December It was the 100th anniversary of the ceremonial opening of the Maritime School in Tczew and the flag-raising of the Polish Merchant Navy on the school building. Over the course of the century, the name and location of the University has changed, but one thing that has remained unchanged to this day is the serving of the Polish sea.

2020 was also a special year for all the world affected by the coronavirus pandemic. The restrictions in force introduced changes to the program on the 100th Anniversary of GMU. In the changed formula, the celebrations on December 8, were held according to the plan adopted by the University.

The solemn session of the Senate on the occasion of the traditional School Anniversary and the 100th Anniversary of Polish Maritime Education was convened in the remote mode. That was an opportunity to present awards and orders of merits for considerable service for the development maritime education and GMU were presented.

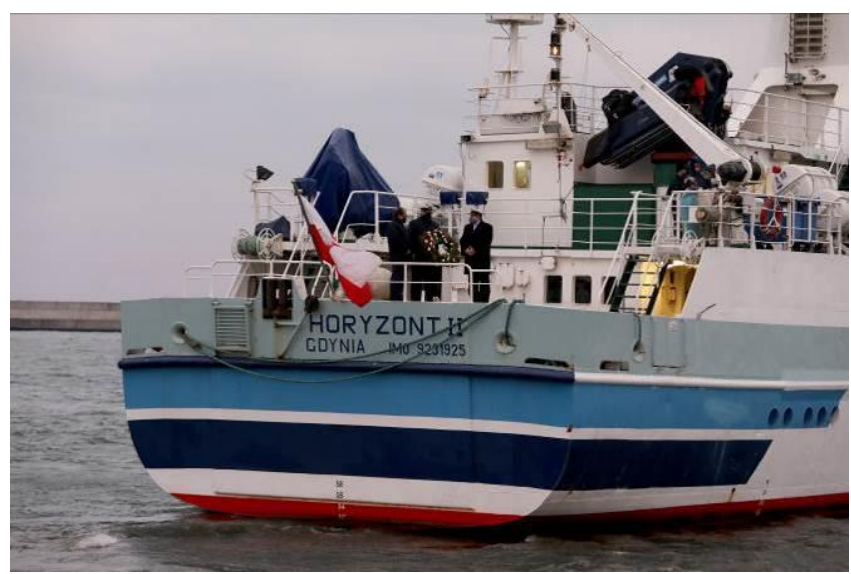

Figure 2. Symbolic wreath thrown into the Gulf of Gdańsk from the deck of the training ship Horyzont II during the annual Memorial Appeal, Dec. 8, 2020
At the Pomeranian wharf, at the mooring point of Dar Młodzieży, a Memorial Appeal was held to honor all those who gone for the eternal watch. With this solemn memorial, we remembered the directors, lecturers, employees, students and graduates of the Maritime School in Tczew and the Gdynia Maritime University, who are no longer with us, and who have become part of the 100-year history of the University.

After reading the Memorial Appeal, organized every year to commemorate the fallen, murdered, missing and deceased students, lecturers and graduates of the University, Rector prof. Adam Weintrit, Secretary of State in the Ministry of Infrastructure Marek Gróbarczyk and Chaplain of the Gdynia Maritime University, Fr. Edward Pracz threw the symbolic wreath into the Gulf of Gdańsk from the deck of the training ship Horyzont II.

On the occasion of the anniversary, we received best wishes and congratulations from universities and institutions cooperating with the GMU.

Special thanks go to:

- Secretary General of the International Association of Maritime Universities (IAMU),

- President of Shanghai Maritime University,

- Rector of Hochschule Bremerhaven,

- Rector of Pîrî Reis Üniversity,

- Rector of Nikola Vaptsarov Naval Academy,

- Rector of National University "Odessa Maritime Academy",

- Rector Commandant of Polish Naval Academy,

- Rector of Academia de pesca e Cincias do Mar do Namibe,

- President of Arab Academy of Science, Technology and Maritime Transport,

- Chairman of the Conference of Rectors of Polish Universities of Technology, Rector of the Silesian University of Technology,

- Rector of Batumi State Maritime Academy,

- Rector of Gdańsk University of Technology,

- Rector of Constanta Maritime University,

- Rector of Warsaw University of Technology,

- Rector of Tallinn University of Technology,

- Rector of Hochschule Wismar University of Applied Sciences Technology, Business and Design,

- The Chancellor of Liverpool John Moores University,

- President and Rector of Satakunta University of Applied Sciences,

- Rector of AGH University of Science and Technology in Cracow,

- Secretary General of the International Hydrographic Organization (IHO).

\section{GDYNIA MARITIME UNIVERSITY (GMU)}

Gdynia Maritime University is the largest state school of higher maritime education in Poland and one of the largest in Europe. Since 1920 the University has been preparing graduates for officer positions on board merchant marine vessels and for managerial positions at the land-based institutions and companies representing the maritime industry and seaside regions. The University four Faculties offer 
degree in Navigation, Management and Quality Science, Marine Engineering, and Electrical Engineering. Currently, the Gdynia Maritime University educates over 5,000 students.

The programs of studies satisfy both Polish educational standards provided by the Ministry of Education and also the requirements of the International Maritime Organization - IMO. The academic staff - representing doctor of science degree and scientific titles of a professor accompanied, in many cases, by the highest marine diplomas of a Master Mariner and Chief Engineer - supported by the laboratory facilities offering 25 specialised simulators and ISO 9001:2015 education quality management system implemented by the University.

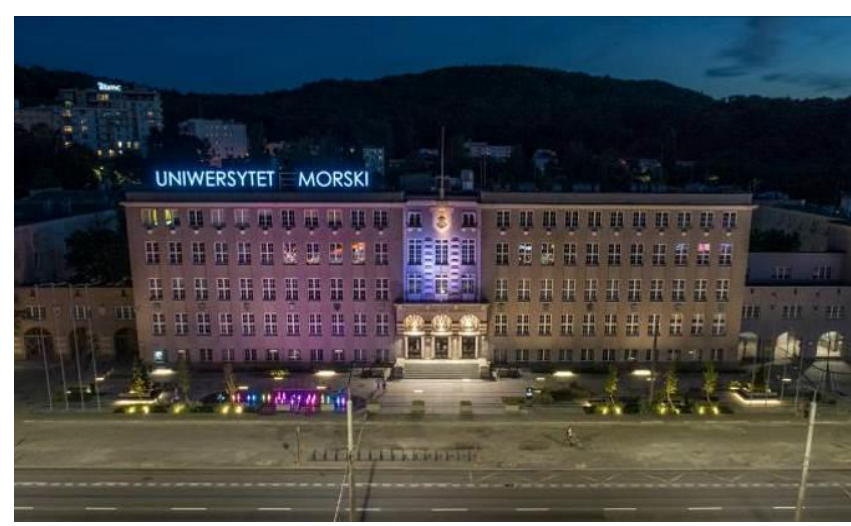

Figure 3. Main building of Gdynia Maritime University, 2020, Gdynia, Morska Str. 81

The Maritime University actively co-operates in the conduct of joint research projects, preparation of young generation academic staff and in the exchange of students with several dozen of maritime institutions of higher education within international organisations such as: European University Association (EUA) and International Association of Maritime Universities (IAMU).

The new strategy for further growth and development adopted by the Senate of Gdynia Maritime University will ensure the strengthening of the University role as a worldwide marine oriented centre of studies and training preparing professionals - citizens of the World.

\section{ROUND-THE-WORLD INDEPENDENCE SAIL}

The centenary of Poland's reappearance on the map of Europe turned out to be the moment when the idea of the great cruises of Dar Młodzieży around the world gained widespread approval and government support. The role of an ambassador was given to the Dar Młodzieży - a genuinely Polish tall ship, built by the Gdansk Shipyard, with her homeport in Gdynia and manned with Polish crew. Throughout her 36 years of service, she trained a massive number of cadets who are employed all over the world on board ships. Combining the anniversary with a visit to Panama during the World Youth Day strengthened and elevated the symbolic importance of that's undertaking.
The voyage was commenced on May 20, 2018 and completed on March 28, 2019.

It was undoubtedly one of the greatest cruises in the history of the Dar Młodzieży, and even more broadly speaking in the history of the white and red flag. The sailing ship covered 38,000 nautical miles, having embarked nearly 1,000 young people in total throughout the period of 313 days - students of maritime schools and winners of the national qualifying competition.

The Independence Sail undertaking aimed at meeting several goals. The first and the foremost one was to promote our country in the context of the centenary of Poland's independence. Entrusting Dar Młodzieży with the task was a very strong point of the whole project. A sailing ship having hundreds of young people on board in total at subsequent stages of the journey, was an attraction herself wherever she entered a port on the route. Together, they spread a clear message about Poland as a country with wellestablished maritime traditions, open to the world, having rich history and deeply rooted in the history of Europe.

The crucial role of ambassadors was played by two major groups of young people. The most numerous group made the students of Gdynia Maritime University. Together with a smaller group of maritime secondary school students, they were undergoing seamanship training, which is an obligatory element of their maritime education. It was supplemented by groups of young people from all over Poland - winners of the qualifying competition. The students were divided into 8 groups and they exchanged one another as the route progressed. A total of 1,000 students took part in the project.

The Dar Młodzieży called at 23 ports - excluding the homeport of Gdynia. From Tallinn to Copenhagen, then the Norwegian fjords of the Stavanger region and ... return to Poland, to Szczecin, to take part in the World Maritime Day Parallel Event being the biggest maritime event of the United Nations and IMO (International Maritime Organization). And from that moment "Dar Młodzieży" headed towards the Great Circle crossing the Danish Straits, calling at Bremerhaven, Bordeaux, and Santa Cruz in the Canary Islands. In each of the ports, a special setting - meetings with representatives of local authorities, performances promoting the independence message of the cruise, active participation of Polish community living abroad and sightseeing of the ship.

On the way to Cape Town, having crossed the equator for the first time during the passage, the Dar Młodzieży entered the southern hemisphere for several months. There, the neophytes experienced the Equatorial baptism being an old maritime ritual. King Neptune and his companions visited the vessel and those who had never crossed the Equator before underwent sophisticated torture. During the trip, Neptune boarded the white frigate for the second time in October between Borneo and Sumatra, before the arrival in Singapore and return to the northern hemisphere.

In the Far East scenery - from Jakarta, through Singapore, Hong Kong - on the day of the hundredth 
anniversary of regaining independence, they reached Osaka. That was the third visit of our sailing ship to this Japanese port. The earlier calls had taken place in 1983 and 1997. This time, the centenary of Poland's Independence was celebrated with the sounds of the national anthem of Poland - "Dąbrowski's Mazurka", also known by its incipit, "Poland Is Not Yet Lost" and ubiquitous white and red colours.

After saying goodbye to Japan, "Dar Młodzieży" started her longest ocean stage of this expedition across the Pacific to the ports of the west coast of the United States. After 32 days she arrived in San Francisco covering the distance of 5,311 nautical miles. For the first time in his history the tall ship visited the ports of California - San Francisco and Los Angeles where they spent the Christmas Eve. The New Year's Eve was celebrated on the way to Mexican Acapulco. The culmination of the trip World Youth Day was held in Panama. The crew comprised of students and winners of the competition participated in that extraordinary allworld meeting. The crew delegation was received by His Holiness Pope Francis.

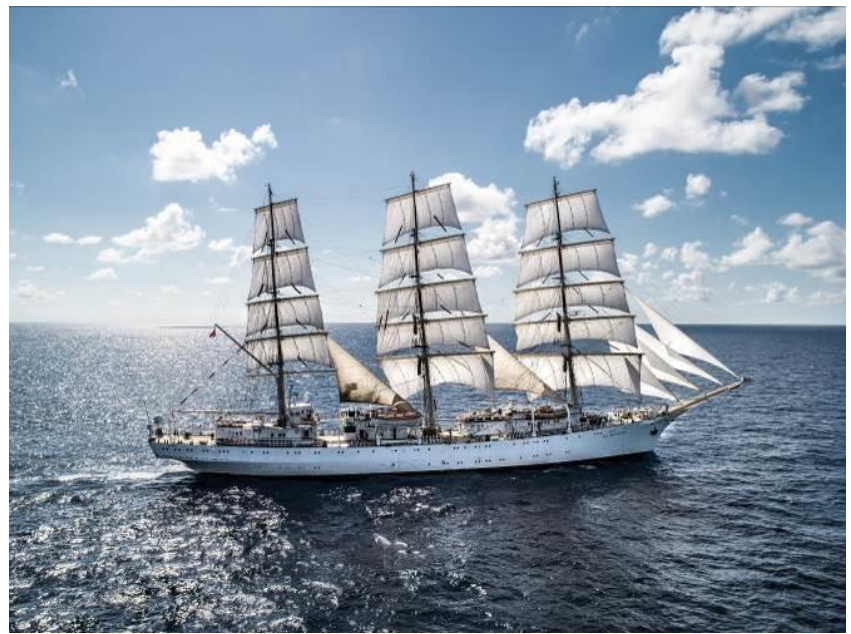

Figure 4. GMU's tall Ship Dar Młodzieży

Panama opened the return stage. Heading towards the Atlantic waters they visited Cartagena and Florida. Two more stops in the Bahamas and Madeira, and on March 13, 2019 at 21.25, in the English Channel, the sailing ship, after traveling 32 487 nautical miles, closed the loop around the world, cutting the course on June 24, 2018.

The twenty-third port of call being the last foreign port on the route of the Independence Sail was London. Ahead of the ship there was only the homeport of Gdynia. On March 28, 2019, in a fairytale scenery, the vessel emerged from an exceptionally thick fog just beside the quay ending the longest passage in her history known as the Independence Sail.

The university is currently run by newly-elected authorities. The elections took place at a symbolic moment - the hundredth anniversary of the establishment of Polish maritime education, and also the hundredth anniversary of Poland's memorable Marriage to the Sea in Puck - a ceremony celebrating Poland's regaining access to the Baltic Sea. The entry into the second century has coincided with unprecedented challenges of a global nature, both in the sphere of politics, economy, social unrest or climate problems requiring solidarity of the whole civilization. The Gdynia Maritime University, as a recognized scientific, research and educational institution with its intellectual potential and facilities, has a significant role to complete in this complex reality. The solemn session of the Senate on the occasion of the traditional School Anniversary and the 100th Anniversary of Polish Maritime Education was convened in the remote mode. That was an opportunity to present awards and orders of merits for considerable service for the development maritime education and GMU were presented.

\section{GMU FACULTIES}

At present, the academic programmes of GMU are organized into four faculties constituting the basic scientific-educational units:

- Faculty of Electrical Engineering,

- Faculty of Marine Engineering,

- Faculty of Navigation, , and

- Faculty of Management and Quality Science (former names: Faculty of Entrepreneurship and Quality Science and Faculty of Administration).

The faculties are composed of departments that conduct research and educational activities within their profiles of studies.

\subsection{Faculty of Electrical Engineering}

The Faculty of Electrical Engineering comprises of 4 departments:

- Department of Ship Automation,

- Department of Marine Electrical Power Engineering,

- Department of Marine Electronics,

- Department of Marine Telecommunications.

The Faculty offers its students varied and modern research and teaching infrastructure that is upgraded in response to the latest technological developments. Lecture halls that are equipped with the state-of-the art audio-visual equipment and laboratories with new generation devices and instruments as well as the free access to the Internet ensure excellent conditions to conduct both scientific research and teaching processes. Among a wide variety of modern laboratory equipment it is necessary to enumerate: the ship automatic control system simulator and the physical model of the shipboard electrical power plant facilitating teaching, research and testing works on new solutions in ship power generation systems, the GMDSS marine communication system simulator that is a complete, real console of this system, objects for real-life satellite communications, devices for prototyping electronic systems as well as computer and network hardware to realise, among others, the Cisco Networking Academy program. Moreover, within the project RIDAM, financed by the European funds, new laboratories of the Faculty of Marine Electrical Engineering were created and fully equipped. The obtained funds allowed starting the following laboratories: 
- Laboratory of Renewable Sources of Energy,

- Laboratory of Virtualisation of Operational Systems and Computer Networks,

- Laboratory of Microwave Technology,

- Laboratory of Satellite Radio Communications,

- Laboratory of Optoelectronics, Photovoltaics and Fibre Optics,

- Laboratory of GMDSS,

- Laboratory of Electromagnetic Compatibility of Radio Communications Systems,

- Workshop of Computer Design and Simulation,

- Laboratory of Automation of Ship Energy Systems,

- Laboratory of Measurement and Control Systems,

- Laboratory of Microprocessor Measurement and Control Sets.

\subsubsection{Education at the Faculty of Electric Engineering}

The basic aim of Gdynia Maritime University has always been to educate highly qualified personnel for maritime industries. Professional careers of this Faculty graduates have been pursued in this specific direction for many years. The Faculty educates electrical engineers, specialists in operation of ship and land-based electrical equipment and automatic control systems. It also educates electronics engineers, specialists in designing and operation of electronic circuits, facilities and systems dedicated for landbased, sea and ship communications systems as well as stationary and mobile telecommunication and computer tele-informatics networks.

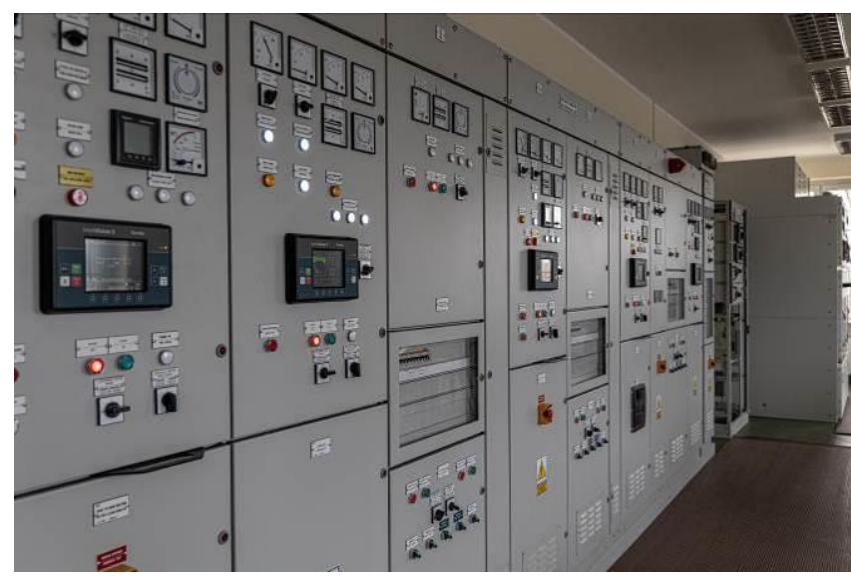

Figure 5. One of the laboratory at Faculty of Electrical Engineering

The graduates in marine specialisations are prepared for positions on ships of the merchant fleet as shipboard electroautomation engineers or shipboard radio electronics and electronics engineers.

The academic staff of the Faculty consists of 19 professors, 11 assistant professors, 13 lecturers and 24 assistants. As many as 13 persons of the staff hold Marine Diplomas and Certificates of Competency authorising them to take officer positions on ships of the merchant fleet.

The Faculty of Electrical Engineering conducts full- and part-time studies of I- and II-cycle (engineer and master) and III-cycle studies (doctoral studies). Two cycles studies (I- and II-), both full-time and part-time, are realised in two fields: Electrical
Engineering and Electronics and Telecommunications.

The field of Electrical Engineering realises education in the following specializations':

- Ship Electroautomation,

- Computer Control Systems,

- Electroautomation.

The field of Electronics and Telecommunications offers studies in the following specialisations:

- Marine Electronics,

- Data Communications Systems and Networks,

- Marine Electronics and Automation

- Electronic, Optoelectronic and Microwave Systems.

In addition, from the academic year 2018/2019 at UM Gdynia, a new one-level study program Informatics is carried out, implemented in two specialisations:

- Internet and Mobile Applications

- Internet of Things Applications

\subsubsection{Scientific research at the Faculty of Electric Engineering}

The Faculty of Electrical Engineering maintains contacts and develops cooperation with the faculties of other Polish universities of the similar profile of scientific and didactic interests. The forms of cooperation include: graduation with doctor degrees, exchange of experience, consulting teaching programmes and offering students the free access to unique laboratories of each particular university. An essential form of this cooperation is participation of the academic staff of other universities in scientific seminars organised by the Faculty Departments. Representatives of the Faculty participate in a number of consultancy bodies such as National Conventions of Deans of Electrical Faculties of Polish technical universities. Many of the Faculty staff also participate in the work of national and foreign scientific organisations.

Particular Departments, depending on their scientific profiles, develop international cooperation with foreign academic and research centres. Representatives of the Faculty also participate in the work of, inter alia: the Institute of Electrical and Electronic Engineers (IEEE), the Institution of Engineering and Technology (IET), the International Centre for Engineering Education (a UNESCO agency), IMO-COMSAR and STCW Subcommittees and the International Mobile Satellite Organisation (IMSO).

The cooperation with foreign centres results in joint realisation of scientific and research projects, joint presentations in international conferences, coorganisation of conferences and exchanges of employees and students.

The Vice-Rectors of three biggest universities of technical profile in Tricity signed on 17th December 2015 an agreement that they will jointly create and conduct II-cycle studies within interuniversity, interdisciplinary field of Space and Satellite Technologies. These studies will be realised jointly by the selected organisational units of Gdańsk University of Technology, Gdynia Maritime 
University and the Polish Naval Academy, including among others the Faculty of Electrical Engineering of GMU. It has been planned that the studies will start in the spring semester of the academic year 2016/2017 and will last three semesters. The new field of studies is a response to the demand of modern companies of the space and satellite engineering sector, which are being set up in the country and the Pomeranian Region as well as the Polish Space Agency established in Gdańsk in 2015 for experts qualified to cope with challenges connected with the development of this sector.

Gdynia Maritime University is an important educational and scientific partner of the company Navimor International Com. in the big international project to create and start operation of the Fishing and Sea Sciences Academy in Namibe, Angola. The Faculty of Electrical Engineering of GMU significantly contributed to realisation of this project. During the first stage of the project (2008-2010) scientists from GMU elaborated the organisational concept and operation plans for the Academy from the didactic and scientific point of view and they also prepared overall plans and teaching curricula. The second stage (2013-2018) involves research and development works of the engineering-technical and expert-consulting character, elaboration of a unique series of 28 academic course books in the Portuguese language dedicated to the selected subjects for 14 specialisations in three Faculties: Fishing, Fish Processing and Water Resources of the Academy in Namibe. This stage also means didactic cooperation concerning education of future staff on II- and IIIcycle studies in GMU for the newly created Academy in Namibe.

\subsection{Faculty of Marine Engineering}

Faculty of Marine Engineering is one of two oldest faculties in Gdynia Maritime University (GMU). The history of the Faculty dates back to the interwar period, when, in 1920, the Maritime School was established in Tczew, with two faculties: navigation and marine engineering.

Nowadays the Faculty comprises of 4 departments:

- Department of Physics,

- Department of Marine Maintenance,

- Department of Engineering Sciences,

- Department of Marine Propulsion Plants.

The mission of the Faculty is to educate students at the highest level and creating employees able to effectively meet the challenges of modern maritime transport and maritime economy in Poland and abroad and to conduct scientific research related to the construction and operation of technical systems in maritime economy.

The Faculty of Marine Engineering of Gdynia Maritime University is the first university faculty in Poland to obtain and hold ISO 9001 quality certificate, which is a guarantee of a high quality of education and research.

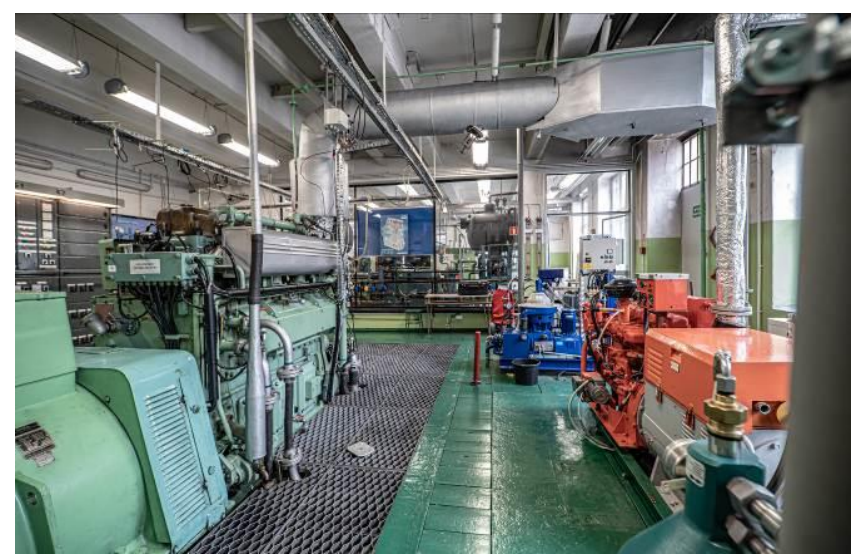

Figure 6. One of the laboratory at Faculty of Maritime Engineering

\subsubsection{Education at the Faculty of Marine Engineering}

The mission of the Faculty is to educate students at the highest level and creating employees able to effectively meet the challenges of modern maritime transport and maritime economy in Poland and abroad and to conduct scientific research related to the construction and operation of technical systems in maritime economy.

The Faculty offers courses in Mechanical Engineering and Machine Design and providing program of studies satisfying both Polish educational standards established by the Ministry of Higher Education and also the requirements of the International Maritime Organization - IMO. We train sea crews (in compliance with STCW 78/95) and professionals employed with onshore industry including repair technologies, operational engineering and production engineering. The graduates of marine specializations obtain a certificate which entitles them to work aboard any merchant vessel all over the world.

The framework of Mechanical Engineering and Machine Design major includes first-degree (engineer) and second-degree (master) studies programmes in the following specializations:

1 First-degree (engineer):

Marine Propulsion Plant and Offshore

Construction Operation (marine specialization) also in English,

- Technology for Repairs of Ship and Port Units,

- Operational Engineering,

- Production Engineering.

2 Second-degree (master's):

- Technology for Repairs of Ship and Port Units,

- Operational Engineering,

- Marine Propulsion Plant Operation 2 (marine specialization).

During their first and second year of studies, students are given maritime training aboard GMU training ships: „Dar Młodzieży” and „Horyzont II”.

\subsubsection{Scientific research at the Faculty of Marine Engineering}

The Faculty of Marine Engineering of Gdynia Maritime University is the first university faculty in Poland to obtain and hold ISO 9001 quality certificate, 
which is a guarantee of a high quality of education and research.

The Faculty employees conduct following scientific research:

- research into the role of foreign substances in shaping light field in the marine environment.

- optimizing the conditions of petroleum products degradation,

- analysis of correlations between technology proceedings at sea and natural environment,

- properties of aluminium alloys and junction connections applied in marine construction,

- evaluation of the possibility of using multiphase shells produced with the use of welding technologies for increasing the operating durability of vessel machine and appliance parts,

- optimizing the parameters for technological processes of surface treatment of marine machine parts,

- research into the running-in process in terms of temperature increase of the working system elements in a machine tool,

- regeneration of machine appliance and machine parts,

- hydrodynamic theory of lubrication,

- marine environment protection,

- research into vessel hull integrity while affected by a blast wave as a result of non-contact underwater detonation,

- theory of shells applied to marine constructions,

- analysis of working processes of combustion engines,

- diagnostics of ship combustion engines,

- analysis of ship propulsion efficacy,

- simulation of ship propulsion processes,

- new generations of ship propulsion.

The faculty has modern didactic and scientific laboratories and equipment, including engine room simulators.

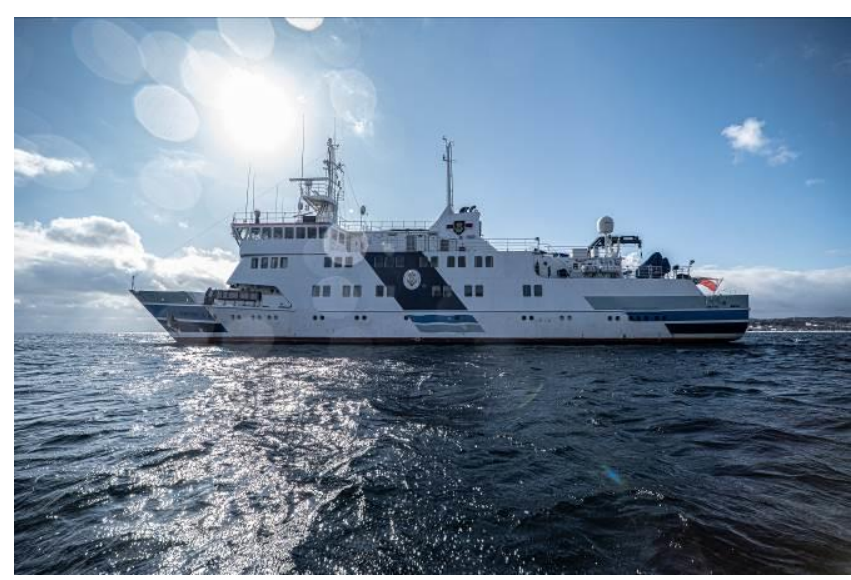

Figure 7. GMU training vessel Horyzont II

\subsection{Faculty of Navigation}

The Faculty of Navigation educates students in two modern fields:

- Transport,

- Navigation.

At present the Faculty of Navigation offers studies in the following specializations:
1 Marine specializations:

- Maritime Transport,

- Safety Management in Maritime Transport,

- Offshore Technologies.

2 Land specializations:

- Transport and Logistics,

- Maritime Transport and Logistics Systems

The aim of studies in the specialization of Maritime Transport is to prepare highly qualified experts in ship operation in maritime transport. Graduates of this specialization obtain a diploma of the accomplished studies and the degree of master and engineer of marine navigator. After doing the training which is strictly specified by the regulations, they also obtain the diploma of officer and are entitled to hold the officer and managerial posts on ships in the deck department.

Nowadays the Faculty comprises of 4 departments:

- Department of Physics,

- Department of Marine Maintenance,

- Department of Engineering Sciences,

- Department of Marine Propulsion Plants.

The mission of the Faculty is to educate students at the highest level and creating employees able to effectively meet the challenges of modern maritime transport and maritime economy in Poland and abroad and to conduct scientific research related to the construction and operation of technical systems in maritime economy.

The Faculty of Marine Engineering of Gdynia Maritime University is the first university faculty in Poland to obtain and hold ISO 9001 quality certificate, which is a guarantee of a high quality of education and research.

\subsubsection{Education at the Faculty of Navigation}

The aim of studies in the Faculty of Navigation is to prepare high class experts both in ship operation in maritime transport and in organisation and operation of transport systems including ports and the seagoing fleet. The first group, after graduation and after completing their ship training in compliance with the relevant regulations, are awarded the Officer Diploma licensing them to perform officer and management functions on merchant ships in the deck department. Comprehensive education complemented with sea training enables graduates to find a job with Polish or foreign ship owners, as well as in companies in the maritime sector.

Studies realised in the field Transport aim at educating highly qualified experts in transport and logistics. Graduates obtain the degree of engineer (Icycle) and the degree of master (II-cycle) and find employment in widely understood international transport and freight forwarding industry. Thanks to the acquired skills to solve complex tasks in transport and logistics and extensive technical-managerial knowledge acquired, including issues concerning operation, functioning, control and management of transport and logistics systems with the use of modern methods and latest information technologies, they are well prepared to take managerial positions in the TSL sector, especially in companies operating in 
the land-sea structures of logistics chains and supply chains.

The scientific-didactic staff includes: 22 professors, 21 assistant professors, 16 senior lecturers and lecturers, and 28 assistants. 17 engineering and technical staff support their work. Among the academic teachers, due to the Faculty profile of educating seagoing staff, there are 35 scientificdidactic workers who hold Marine Diplomas and Certificates of Competency authorising them to take officer positions on merchant ships.

The Faculty provides full-time and part-time studies within the system of I- and II-cycle (engineer and master respectively). Moreover, it is authorised to award a doctoral degree of technical sciences and a post-doctoral degree of technical sciences in the scientific discipline of Transport.

During their first and second year of studies, students are given maritime training aboard GMU training ships: „Dar Młodzieży”.

\subsubsection{Scientific research at the Faculty of Navigation}

The Faculty of Navigation conducts scientific research works concerning the widely understood topic of safety at sea and the issues associated with ship, ship systems and port operations.

The Faculty can pride itself with numerous innovative scientific research works and programmes that have found their practical implementation. The main areas of research and development work are connected with governmental economic or social programmes as well as with international programmes for scientific and scientific-technical cooperation.

The scientific and didactic activities of particular Departments of the Faculty of Navigation are characterised by high thematic diversity, which results from a vast variety of specialisations.

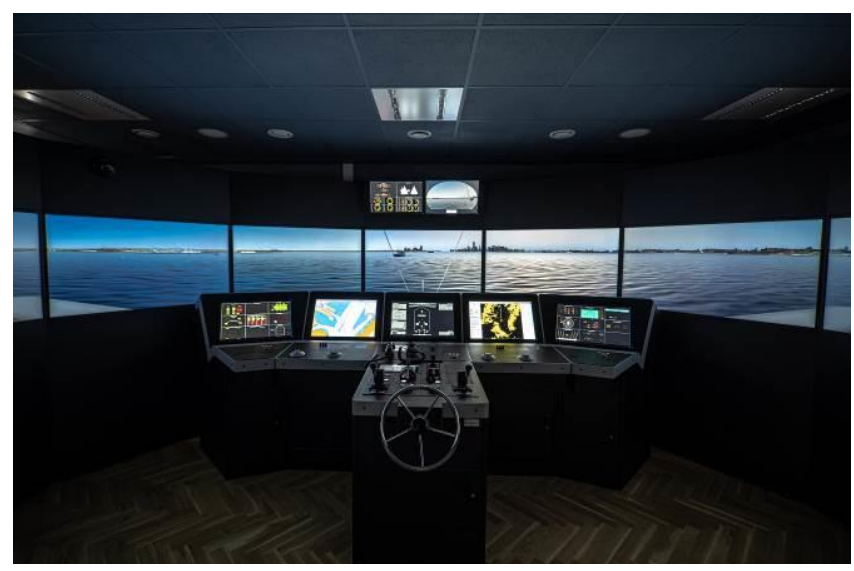

Figure 8. Full Mission Bridge Simulator at Department of Navigation

\section{Department of Navigation}

The Department multidisciplinary scientific and research activities concern the issues related to the generally understood safety in navigation, the process of terrestrial navigation, astro-, radio- and electronic navigation and navigation with new generation navigational devices and electronic navigational charts. Moreover, there are works performed on modelling and optimisation of transport processes as well as navigational software design and testing. Department conducts scientific research on development of navigational systems, including GNSS, GIS, ECDIS, INS and eNavigation.

2 Department of ship operation

The scientific research works conducted by the Department involves the areas of safety modelling and reliability of search and rescue actions at sea.

Another area of interest are the issues concerning ship propulsion and thrusters. In addition, the Department performs works on cargo handling, including the latest technologies, creating model carriage instructions for various cargoes on seagoing ships as well as management of safe ship operation. The research concerns also the issues related to manoeuvring ships of various manoeuvring characteristics, protection of marine environment against pollution as well as ship stability and hull strength. Moreover, research and scientific activities focus on the issues of maritime law related to maritime trade turnover recodification of the Polish maritime law and legal restrictions concerning international contracts.

3 Department of Geodesy and Oceanography

The scientific research activities of the Department involve two scientific disciplines - geodesy and cartography and oceanography. Within the discipline of geodesy and cartography the main areas of scientific research are the issues related to satellite geodesy, higher geodesy and geodetic astronomy, geographical information systems, river information systems RIS, engineering geodesy (railway geodesy) and hydrography. Within the discipline of oceanography the Department conducts scientific research on interactions of the atmosphere and ocean taking into consideration currently occurring climatic changes. Three basins are of particular interest: the Arctic - because of hydroclimatic changes occurring there, the Atlantic Ocean - because of changeability and changes in weather and climatic conditions and finally, the Baltic Sea - because of changeability and changes in weather and hydroclimatic conditions.

4 Department of Mathematics

The main area of scientific research work is the theory of probability and mathematical statistics with their applications in modelling reliability, safety and systems operation, particularly transport systems.

5 Department of Transport and Logistics

The scientific research activities are focused on effectiveness and efficiency of operation and development of transport and logistics systems in their numerous spatial, technical, economic, legaladministrative and social relations with the national and international environment. The works also concern the issues of transport with regard to logistics chains and supply chains. Special area of interest of the Department are technical-technological and economic-regulatory problems in the development of maritime transport - in navigation and sea ports on the European (EU) and global scale. 


\subsubsection{National and international cooperation}

Every two years the Faculty of Navigation together with The Nautical Institute organises the International Conference TransNav on Marine Navigation and Safety of Sea transportation. Scientific-didactic workers of particular Departments participate in many international and national congresses, symposia and conferences. These include among others: IALA congresses, European Navigation Conferences, European symposia GNSS, ICCGS, ESREL, conferences on safety and reliability, conferences on the role of navigation in securing human activities at sea, conferences on sea traffic engineering, conferences on maritime, inland and road transport, and many others.

The Faculty staff is a member of many organisations: Committee of Geodesy and Committee of Transport of the Polish Academy of Sciences, Navigation Safety Section of the IMO National Centre, Sail Training Association Poland, the Committee of Polar Research of the Polish Academy of Sciences, the National Committee of the Geographic and Nautological Competition. Some of the Faculty staff are also members of such British organisations as: The Royal Institute Of Navigation and The Nautical Institute.

\subsection{Faculty of Management and Quality Science}

The Faculty of Management and Quality Science educates students for onshore jobs in the maritime economy and regional institutions. Its offer includes I-cycle and II-cycle studies. The Faculty has the right to grant doctoral degrees and post-doctoral degrees in economic sciences within the scope of commodity science.

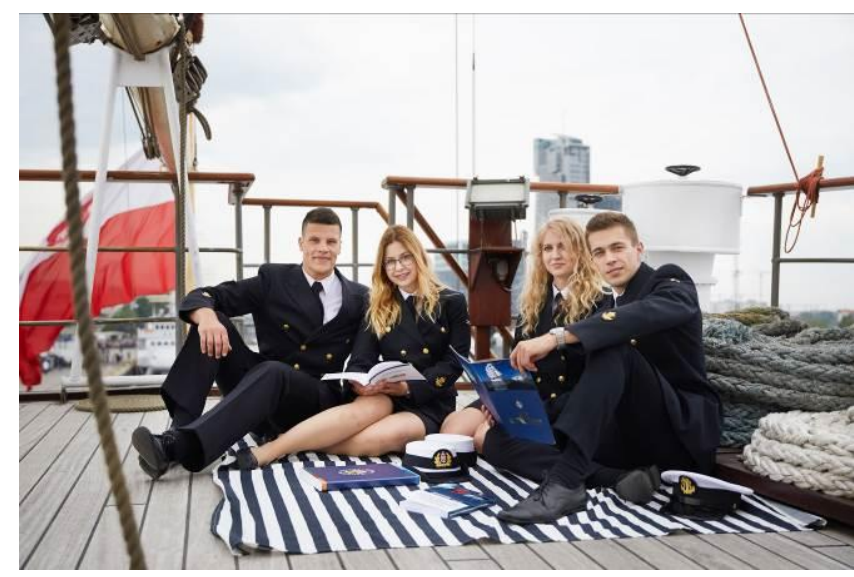

Figure 9. Students rest on the aft deck of Dar Młodzieży.

Nowadays the Faculty comprises of 5 departments:

- Department of Commodity Science and Quality Management,

- Department of Industrial Commodity Science and Chemistry,

- Department of Information Systems,

- Department of Logistics and Transport Systems,

- Department of Management and Economics.

The mission of the Faculty is "to conduct scientific research and commercialise its results and findings, raise the quality of students' education, cooperate effectively with the economic surroundings and create organisational conditions for development of the academic community of the Faculty".

\subsubsection{Education at the Faculty of Management and Quality Science}

The Faculty of Management and Quality Science educates students for onshore jobs in the maritime economy and regional institutions. Its offer includes I-cycle and II-cycle studies in two fields: Innovative Economy and Quality Science.

The programmes of undergraduate (I-cycle) studies in Innovative Economy include: Managerial Economics, Business Informatics, Transport and Logistics Systems, Tourism and Hospitality, Maritime Economics and Logistics -studies in English

The programmes of post-graduate (II-cycle) studies include: E-business, Innovation Manager, Accounting and Finance, Transport and Logistics in the Global Economy, International Trade, Transport and Logistics - studies in English.

The programmes of undergraduate (I-cycle) studies in Commodity Science include: Product Manager, Commodity Science and Quality Management, Food Services and Dietetics.

The programmes of post-graduate (II-cycle) studies include: Commodity Science and Quality Management, Nutrition and Dietetics, Water Protection and Waste Management.

The programmes of post-graduate studies in Management and Quality Science include: Logistics and International Transport, Nutrition and Dietetics Services, Project Management.

\subsubsection{Scientific research at the Faculty of Faculty of Management and Quality Science}

The staff of the Faculty realise numerous scientific and research projects, both national and within international consortiums. The submitted project proposals obtain support from the Ministry funds (among others: National Science Centre) and are also financed by the European programmes and institutions (e.g. Horizon 2020, Interreg BSR, CBSS, Swedish Institute).,

\section{GMU MARITIME INSTITUTE}

Maritime Institute (previously known as the Maritime Institute in Gdańsk) became a research unit of the university aimed at implementation of commercial projects (outsourced, research and expert works), projects financed from external sources (State, European, international), and scientific projects and research for the benefit of the marine economy and associated sectors, including the energy, shipping and seaports, maritime tourism, and cultural heritage.

The Maritime Institute (MI) became the Polish offshore market leader in the field of environmental surveys and development of environmental, 
geophysical, geological, and geotechnical documentation for offshore investments, the wind energy sector in particular. It is also a centre of knowledge and competence, where information on the needs and priorities of the maritime economy and the use of marine resources (including marine space management) is processed and evaluated. Furthermore, this unit is active in various research and development projects in the area of environmental protection and marine resources and water ecology including sea fisheries. The Institute performs highly specialised laboratory tests in the fields of chemistry, biology, and maritime geotechnics, provides expertise on maritime hydrotechnics, and operationalises artificial intelligence in transport to optimise the logistics process and promote ecological transport.

The structure of the Maritime Institute consists of departments and divisions such as:

- Department of Marine Ecology (DME),

- Department of Economics and Law (DEL),

- Department of Maritime Geotechnics (DMG),

- Department of Maritime Hydrotechnics (DMH),

- Department of Operational Oceanography (DOO),

- Department of Environment Protection (DEP),

- Maritime Electronics Division (MED),

- Spatial Policy Division (SPD).

There are also three PCA accredited research laboratories of the DEP, MED, and DMG, which operate as parts of the Institute. The Maritime Institute has adopted the Integrated Management System based on the ISO 9001, ISO 14001, and OHSAS 18001 Standards.

A key resource qualifying the Maritime Institute to engage in the above-mentioned activities is its research vessel - the multi-purpose oceanographic research laboratory $\mathrm{r} / \mathrm{v}$ Imor. The vessel is equipped with state-of-the-art gear and measuring instruments, maintained in perfect shape by a team of mechatronics engineering technologists of the DOO.

Offshore surveys conducted by the Institute require collecting and processing large amounts of measurement data, which is why its disc array (of 1.0 PB capacity) operated by a strong team of software developers and IT professionals focusing on the analytical processes is an information centre of the Institute.

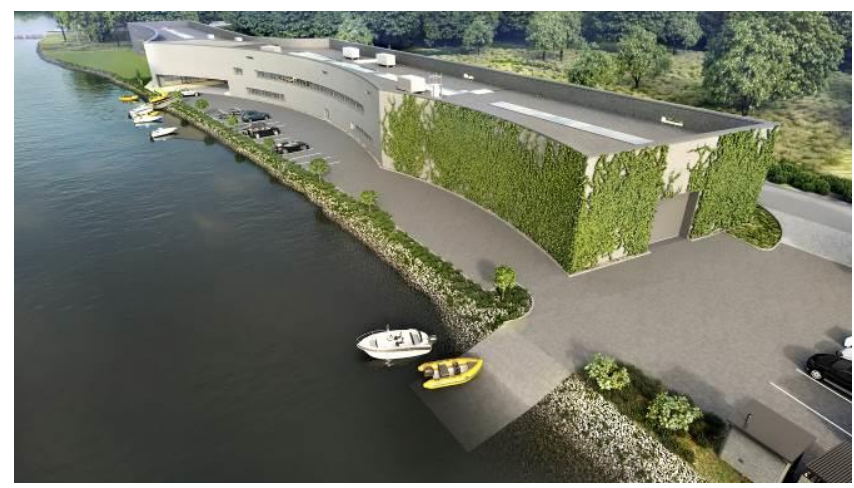

Figure 10. Mockup of the planned new headquarters of the GMU Maritime Institute, with location in Gdańsk next to the fortress Wisłoujście
The MI operates its own Project Services Centre, which supports its departments and divisions in the research project development, application, and project-accounting, especially in the case of projects financed funded through EU programmes. In effect, the Institute creates and supports international research and development projects financed from national and international funds, and becomes their leader.

The programme for the development of offshore wind energy in Poland, i.e. the sector in which investments worth PLN 130 billion are planned for the next few years, is one area of particular interest for the Maritime Institute. Performing research, developing cutting-edge methods of marine environment analysis, supporting businesses and authorities in the investment process, as well as expanding capacities for the educational process in favour of offshore wind energy are of priority importance for the Maritime Institute in line with the development strategy adopted by the Gdynia Maritime University.

\section{SHIP HANDLING RESEARCH AND TRAINING CENTRE AT IŁAWA}

The Ship Handling Research and Training Centre at Iława is owned by the Foundation for Safety of Navigation and Environment Protection, which is a joint venture between the Gdynia Maritime University, the Technical University of Gdansk and the City of Iława.

Two main fields of activity of the Foundation are:

- Training in ship handling. Since 1980 more than 4800 ship masters and pilots from 40 countries were trained at Iława Centre. The Foundation for Safety of Navigation and Environment Protection, being non-profitorganisation is reinvesting all spare funds in new facilities and each year to the existing facilities new models and new training areas were added. Existing training models each year are also modernised, that's why at present the Centre represents a modern facility perfectly capable to perform training on ship handling of shipmasters, pilots and tug masters.

- Research on ship's manoeuvrability. Many experimental and theoretical research programmes covering different problems of manoeuvrability (including human effect, harbour and waterway design) are successfully realised at the Centre.

\subsubsection{Research on Ships Manoeuvrability}

The Foundation for Safety of Navigation and Environment Protection offers consulting and assistance in the design of ships.

The offer includes:

- prediction of manoeuvring characteristics in the early design stage using computer simulation based on own mathematical model;

- verification of manoeuvring characteristics according to IMO requirements for which free running model tests are usually applied. 
Research facilities of the Iława Centre are particularly suitable to realisation of the process of design and optimisation of waterway and harbour layouts. Mock-ups of tested areas and free running manned models are very effective in solving problems of safe manoeuvring on restricted waters. Desktop simulator technique, when needed, is also applied.

\subsubsection{Training in Ship Handling}

Each year new items have been included into the course programme, so that the actual programme differs much from the training realised some years ago. The new training areas together with introduction of the new models of modern ships and with the modernised and new equipment of other training models give now the possibility of realisation of the two stage training programme comprising standard and advanced course. There is also a possibility to introducing of specialised courses focused on chosen problems of manoeuvrability or including training on specific types of ships.

This was expected by several customers, for which we offered until today only basic manned model course on ship handling (organised according to STCW 1995 Code and to A.960 Resolution). New proposed training courses are introduced in order to keep pace with the development of technology of shipping and shipbuilding, introduction of new ship types having different manoeuvring characteristics, and fitted with new propulsion and control devices.

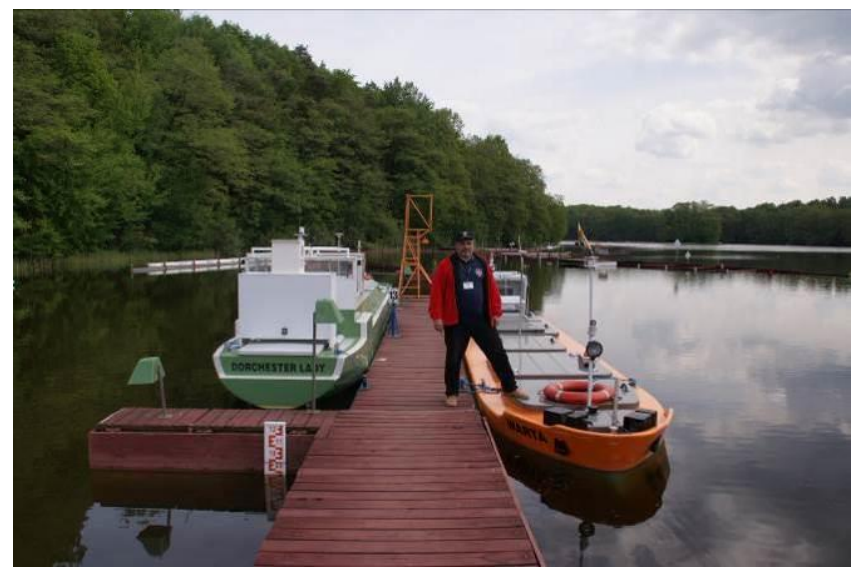

Figure 11. The Ship Handling Research and Training Centre at Iława

Actually the below listed manned model courses are available at Iława Training Centre. Programmes of all courses may be extended - if possible - with manoeuvres resulting from individual needs of trainees.

- handling of large ships and ships with unusual manoeuvring characteristics (basic level) duration 5 days; 2 versions: for masters and for pilots;

- handling of large ships and ships with unusual manoeuvring characteristics (advanced level) duration 5 days; 2 versions: for masters and for pilots;

- handling of very large and ultra large container vessels - duration 4 days;

- handling of LCCs and VLCCs - duration 3 days;
- handling of large container and ro-ro vessels duration 3 days;

- handling of large LNG carriers - duration 3 days;

- tug-ship cooperation - duration 3 days;

- offshore ship handling - duration 3 days;

- handling of twin screw ships - duration 3 days;

- emergency ship handling - duration 3 days;

- handling of ships equipped with podded propulsion units - duration 3 days;

- handling of large PCCs - duration 3 days;

- handling ships equipped with high lift rudders duration 3 days.

\section{EDUCATION AND TRAINING DURING COVID-19}

2020 was a special year for the entire world affected by the coronavirus pandemic. The restrictions in force have introduced changes not only to the program for the 100th anniversary of AMG, but most of all they changed the approach to many problems, including maritime education and training. GMU participated very actively in these efforts, becoming one of the leaders among maritime universities in the world, exchanging with partners its observations, experience and solutions in distance learning and e-learning.

The GMU is active member of International Association of Maritime Universities (IAMU). On 1314 January, 2021 will be organized IAMU Webinar: MET during the COVID-19. This webinar is jointly organized by the Academic Affairs Committee (AAC) under chairmanship Prof. Adam Weintrit, Chairman of IAMU's AAC and the Secretariat of IAMU for member universities to exchange experiences on Maritime Education and Training (MET) during the COVID-19 and to explore a "new normal" in MET. The following topics are scheduled:

- Online/distance teaching and assessments,

- Delivery methods of practical aspects (simulator, face-to-face training) at university,

- Challenges in on-board training programme, and

- New normal in MET.

The main objectives are the following:

- to share the experiences on Maritime Education and Training during COVID-19 with member universities

- to give an opportunity to build future networking among academic staffs of member universities

\section{CONCLUSIONS}

The experience of the Gdynia Maritime University in the face of the challenges of the modern world is based primarily on maritime education in a broad sense - on the active participation of the University's representatives in the co-creation, modification and full implementation of the STCW convention, as well as on flexible adaptation of specialties and academic programs to the European and national Qualifications Framework and for the needs of the global and local labour market. Secondly, in the maritime area - we are basically oriented to the problems of maritime 
transport, and their main emphasis is on the implementation of new technologies, effective and reliable technical and organizational solutions that are user-friendly and environment-friendly, such as green shipping, development of e-navigation concept, offshore technology, renewable energy, MASS (Maritime Autonomous Surface Ship), reduction of gases emissions, etc.

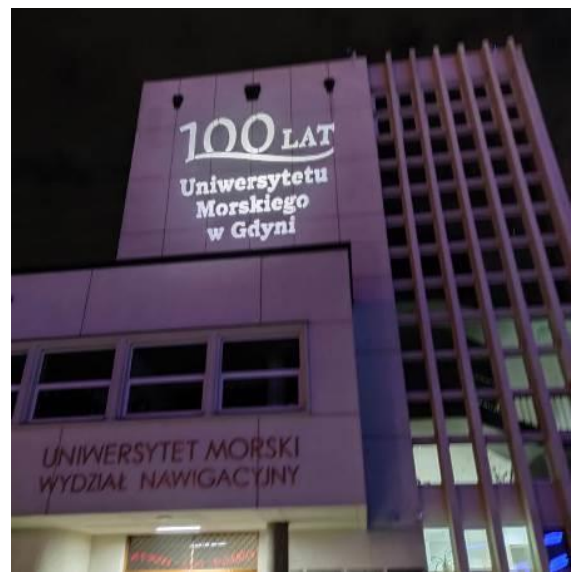

Figure 12. Gdynia Maritime University, The Faculty of Navigation is celebrating the 100th Anniversary of GMU

Our main goal is the analysis of and the consequences resulting from the present challenges that the maritime universities face, as well as the multi-aspects discussion of some ways and solutions based on the Gdynia Maritime University's experience, how to overcome these challenges. The presented approach deals with two domains, maritime education and marine transport-based research, respectively.

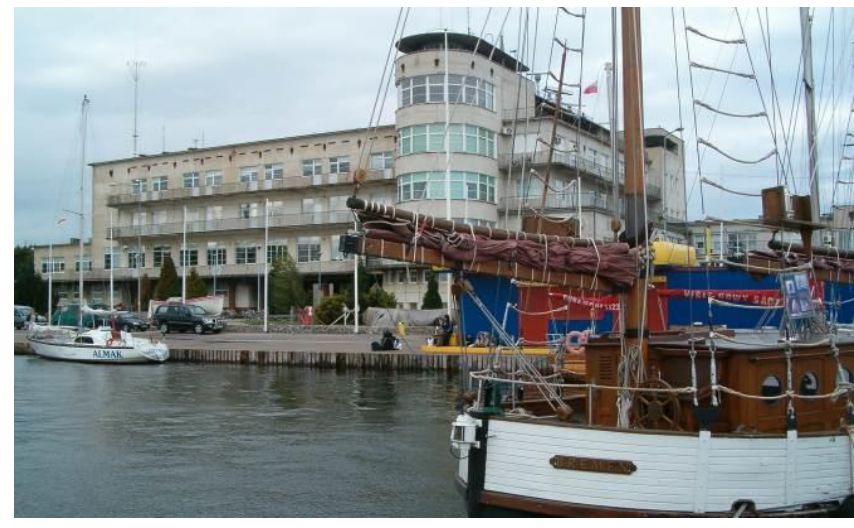

Figure 13. The Faculty of Navigation in the summer season

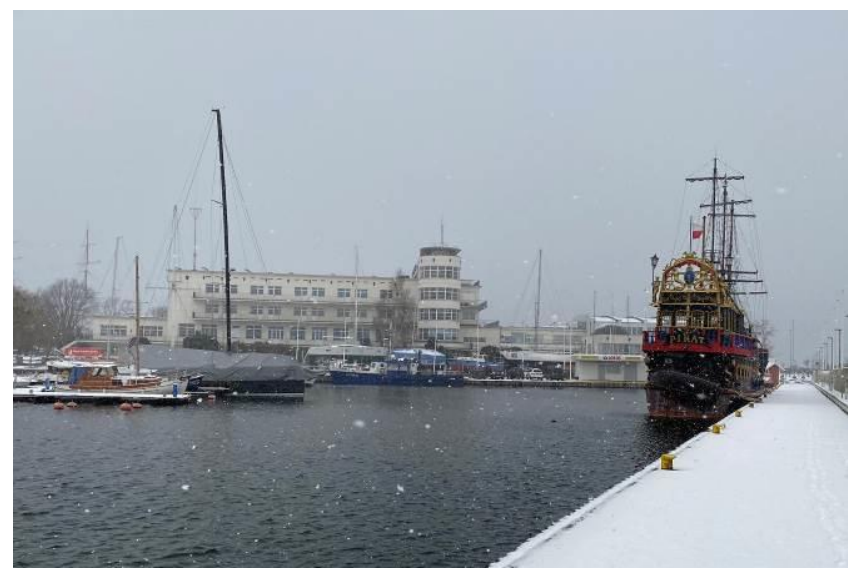

Figure 14. The Faculty of Navigation in the winter season

\section{REFERENCES}

Czarnecka A., Gosk A.: Od Szkoły Morskiej w Gdyni do Uniwersytetu Morskiego w Gdyni. 100 lat w służbie polskiemu morzu (in Polish). Uniwersytet Morski, Gdynia 2020.

Mindykowski J., Charchalis A., Przybyłowski P., Weintrit A. 2012. Maritime education and research to face the XXI-st century challenges in Gdynia Maritime University experience, BIT's Annual World Congress of Ocean 2012, Book of summaries, p. 183, Dalian, China.

Mindykowski J., Charchalis A., Przybyłowski P., Weintrit A.: Maritime Education and Research to Face the XXI-st Century Challenges in Gdynia Maritime University's Experience Part I - Maritime Universities Facing Today and Tomorrow's Challenges. TransNav, the International Journal on Marine Navigation and Safety of Sea Transportation, Vol. 7, No. 4, doi:10.12716/1001.07.04.13, pp. 575-579, 2013

Mindykowski J., Charchalis A., Przybyłowski P., Weintrit A.: Maritime Education and Research to Face the XXI-st Century Challenges in Gdynia Maritime University's Experience Part II - Gdynia Maritime University of Experience the 21st Century Challenges. TransNav, the International Journal on Marine Navigation and Safety of Sea Transportation, Vol. 7, No. 4, doi:10.12716/1001.07.04.14, pp. 581-586, 2013.

Sawicki J.K.: Polish Maritime Staff. Volume 1. Polish Marchant Navy. Gdynia Maritime Academy, Gdynia 2000.

Sokołowska M., Degórski T.: Per Mare Ad Astra. 100 lat Morskiej Szkoły 1920-2020 (in Polish). Fundacja Lechosława Bar Wsparcia Edukacji Morskiej, Gdynia 2020.

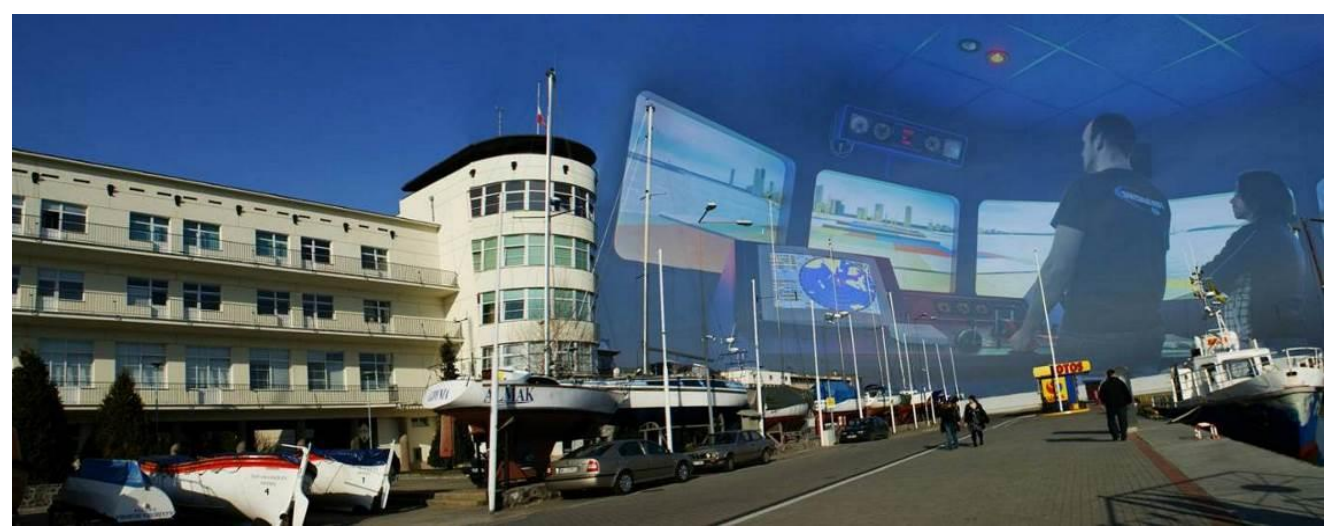

Figure 15. Gdynia Maritime University, The Faculty of Navigation 